NBER WORKING PAPER SERIES

\title{
THE EFFECTS OF PROGRESSIVE INCOME TAXATION ON JOB TURNOVER
}

\author{
William M. Gentry \\ R. Glenn Hubbard \\ Working Paper 9226 \\ http://www.nber.org/papers/w9226

\section{NATIONAL BUREAU OF ECONOMIC RESEARCH 1050 Massachusetts Avenue Cambridge, MA 02138} \\ September 2002
}

We thank Bertil Holmlund, Jim Poterba, and seminar participants at the Trans-Atlantic Public Economics Seminar and the University of California at Berkeley for helpful comments. We are grateful to Anne Jones and Manuel Lobato Osorio for excellent research assistance. The views expressed herein are those of the authors and not necessarily those of the National Bureau of Economic Research.

(C) 2002 by William M. Gentry and R. Glenn Hubbard. All rights reserved. Short sections of text, not to exceed two paragraphs, may be quoted without explicit permission provided that full credit, including (C) notice, is given to the source. 
The Effects of Progressive Income Taxation on Job Turnover

William M. Gentry and R. Glenn Hubbard

NBER Working Paper No. 9226

September 2002

JEL No. H3

\begin{abstract}
$\underline{\text { ABSTRACT }}$
We examine whether the level of the income tax rate and the convexity of the income tax schedule affect job mobility, as measured by moving to a better job. While the predicted effect of the level of the tax rate is ambiguous, we predict that an increase in the convexity of the tax schedule decreases job search activity by taxing away some of the benefits of a successful job search. Using data from the Panel Study of Income Dynamics, we estimate that both higher tax rates and increased tax rate progressivity decrease the probability that a head of household will move to a better job during the coming year. Our estimates imply that a five-percentage-point reduction in the marginal tax rate increases the average probability of moving to a better job by 0.79 percentage points (a 8.0 percent increase in the turnover propensity) and that a onestandard- deviation in our measure of tax progressivity would increase this probability by 0.86 percentage points (a 8.7 percent increase in the turnover propensity).
\end{abstract}

William M. Gentry

602 Uris Hall

Graduate School of Business

Columbia University

New York, NY 10027

and NBER

wmg6@columbia.edu
R. Glenn Hubbard 609 Uris Hall

Graduate School of Business

Columbia University

New York, NY 10027

NBER

and Council of Economic Advisers

rgh1@columbia.edu 


\section{THE EFFECTS OF PROGRESSIVE INCOME TAXATION ON JOB TURNOVER}

\section{Introduction}

A variety of models of promotion, efficiency wages, and job search predict that nonlinear payoffs create incentives for labor market effort. Existing empirical work on these models often focuses on specific groups of individuals, such as corporate executives, rather than the general population. Differences across households in the nonlinearities in the tax system that they face provide a source of variation that allows for the econometric identification of the responsiveness of labor market behavior to nonlinear payoffs using the general population. In this paper, we analyze effects of nonlinear payoffs on job turnover. In particular, we focus on how nonlinearities in the tax system affect job turnover. ${ }^{1}$

Rather than estimate the effects of the tax system on the behavior of the unemployed, we focus on job turnover as an indicator of on-the-job search for two reasons. First, in the US context, the dramatic effects of the Unemployment Insurance system (see, e.g., Meyer, 1990) on search behavior probably dwarf the effects on the non-linearities in the income tax. Second, our methodology for measuring tax incentives takes the current employment situation as given.

The importance of job mobility for wage growth (see, e.g., Topel and Ward, 1992) suggests that a relationship between our analysis and the "black box" of recent research on the responsiveness of taxable income to marginal tax rates. As pioneered by Feldstein (1995), this research focuses on how tax rates affect the elasticity of taxable income, which summarizes a wide variety of possible behavioral responses to the tax system. This elasticity is an important

${ }^{1}$ Methodologically, we build on our analysis in Gentry and Hubbard (2002a) of how the level of tax rates and the convexity of the tax system affects individuals' decisions to enter into entrepreneurship. 
policy parameter for both revenue estimates and the efficiency of the tax system. Feldstein and subsequent work by Auten and Carroll (1999) and Gruber and Saez (2000) analyze tax returns to focus specifically on taxable income. In contrast, we examine a specific behavior that should contribute to overall income growth, even if traditional measures of labor supply (i.e., hours worked) are unresponsive to tax rates. Moreover, we allow for both the level of tax rates and the convexity of the tax system to affect behavior.

Recent research in a variety of areas has pointed out that convexities in tax and transfer programs can have strong (and sometimes unintended) behavioral effects. For example, using simulation models, Hubbard, Skinner, and Zeldes (1995) find that nonlinearities introduced by asset-based, means-tested social insurance programs help explain the low saving of low-income households; Gruber and Yelowitz (1999) find empirical evidence of these affects using data on Medicaid eligibility. For unemployment, Meyer (1990) finds that discontinuities in unemployment insurance benefits (e.g., the expiration of benefits) have large effects on the duration of unemployment. Feldstein (1995a) and Dick and Edlin (1997) point out that a nongovernment program - means-tested college financial aid rules - can affect household saving behavior. Continuing in this line of argument, we emphasize the behavioral consequences of tax policy when uncertain returns to investments face a convex tax schedule. ${ }^{2}$

Outside the context of public policy, nonlinearities in rewards play a major role in incentive contracting models (see, e.g., Holmstrom and Milgrom, 1987; and the survey in

\footnotetext{
${ }^{2}$ Our model of the effects of nonlinearities in the tax system departs from the traditional approach to analyzing effects of taxes on labor supply (see Hausman, 1985) that emphasizes how workers choose the number of hours to work when facing a nonlinear budget constraint. In addition to these traditional labor supply effects, our point is that when the "wage rate" is uncertain, a nonlinear tax system can affect employment choices even for a given number of hours.
} 
Prendergast, 1999). In these models, principals offer managers (agents) a nonlinear compensation schedule to help align the manager's incentives with those of the principal. With an incentive contract, the agent's income increases when outcomes are good; in contrast, tax progressivity implies the opposite - the return to success is lower than it would be with less progressive taxes. While the theory of such contracts is well developed, empirical tests of these models have been limited (see, e.g., Prendergast, 1999; and Himmelberg and Hubbard, 2000). By analogy, we test whether behavior responds to the extent to which returns are nonlinear.

Using time-series and cross-sectional variation in tax schedules faced by households in the Panel Study on Income Dynamics (PSID) over the period from 1979 to 1993, our results imply that moves to better jobs are more likely when tax rates are low and the tax system is less progressive. Our estimates of probit regressions imply that a five-percentage-point reduction in marginal tax rates increases the probability that a head of household moves to a better job during the coming year by 0.79 percentage points (which is a 8.0 percent increase in the turnover propensity). We estimate that a one standard deviation decrease in our measure of tax progressivity faced by the household would increase this probability by 0.86 percentage points (an increase in the turnover propensity of 8.7 percent).

The remainder of the paper is organized as follows. Section II presents theoretical predictions of how income taxes may affect job search with particular attention on the effects of progressive taxation. In section III, we discuss our empirical strategy for measuring the effects of tax progressivity on job search activity. Section IV presents our empirical results, and section V concludes with a discussion of the implications of our research and possible extensions. 


\section{Theoretical Predictions of How Taxes Affect Job Search}

Our focus on on-the-job search and job changes leads us to concentrate on different aspects of job search than are generally analyzed in research on search. Much of the analysis on search focuses on how individuals set reservation wages, the impact of these decisions on the duration of search, and the implications for unemployment. ${ }^{3}$ That is, a central concern of the search literature is, given that an individual is searching, when will he or she accept a job? For general surveys of the search theory in labor markets, see Mortensen (1986) and Mortensen and Pissarides (1999). Despite the previous emphasis on the search behavior of the unemployed, a substantial fraction of new employees come from switching jobs instead of from unemployment so the determinants of who engages in on-the-job search are important from the perspective of overall job turnover (see Pissarides and Wadsworth, 1994, for previous empirical evidence on on-the-job search).

Despite the importance of search theory in the analysis of government policies toward unemployment, little research has been done on the effects of income taxes and job search behavior. For unemployed job searchers, the effects of social insurance programs and unemployment benefits are critical for determining the reservation wage in the job search process and the intensity of job search. The income tax also plays a role by affecting the replacement rate of unemployment benefits and the after-tax distribution of offers. For on-thejob search, social insurance programs are less relevant for job search decisions than they are for the unemployed searchers and the effects of the income tax on the offer distribution are

\footnotetext{
${ }^{3}$ The empirical research has examined how the duration of search, the methods of search, the intensity of search (e.g., number of contacts), the reservation wage, and the accepted wage are related to characteristics of the searchers and the search environment (see, e.g., Blau and Robbins, 1990).
} 
relatively more important.

While our empirical analysis focuses on moves to better jobs, previous theoretical models of the traditional job search issues reinforce some of our predictions. Ljungqvist and Sargent (1995) argue that an increase in the progressivity of the tax system will reduce unemployment for two reasons. First, by reducing the benefits to finding a better paying job, an increase in progressivity will reduce the voluntary unemployment rate; this effect is the focus of our empirical analysis. Second, as also discussed by Pissarides (1983 and 2000) and Manning (2001), an increase in progressivity of the income tax system will reduce involuntary unemployment by reducing the reservation wage during a job search since the progressivity reduces the benefit of holding out for a better offer. ${ }^{4}$ Furthermore, for the unemployed, as discussed theoretically by Pissarides (1998 and 2000) and demonstrated empirically by Meyer (1990), the features of the unemployment insurance system are critical for understanding search behavior. Incorporating the complicated non-linearities of the U.S. unemployment system are beyond the scope of our analysis.

Because our methodology for measuring tax incentives is ill-suited for studying search duration, reservation wages, or other issues associated with unemployment, we focus on the decision whether to search or to change jobs instead of offering formal econometric tests of specific implications of search theory for the search duration or reservation wages. In a sense, "job search" in our context is just one example of effort that an individual can exert to improve his or her future labor market opportunities. Given this context, we are drawn to models of job

\footnotetext{
${ }^{4}$ While much of Manning's focus is on how taxes affect reservation wages for job searchers, he does conjecture that increasing the marginal tax rate is "likely to have an adverse impact on search intensity as it reduces the reward from higher-wage jobs."
} 
search that resemble more general treatments of human capital investment. Rather than provide a comprehensive review of how taxes may be incorporated into search models, the purpose of the remainder of this section is to develop the hypothesis that the extent of progressivity in the income tax system may affect search incentives.

Kesselman's (1976) model of tax effects on job search provides a useful starting point. He assumes that individuals divide their time between leisure, working, and searching. The search component can be interpreted as search or networking effort for workers who frequently change jobs or, more generally, as a form of off-the-job training. Search effort increases the wage rate for the time spent working and these returns to search effort are assumed to be certain. Kesselman assumes a utility function over leisure and consumption that has equal disutility on working or searching so the time allocation problem can be broken into two stages. For any given amount of leisure, the individual allocates time between working and searching; given these allocations of time, the individual chooses the optimal bundle of leisure and consumption. The income tax system is assumed to be linear.

In this model, an increase in the marginal tax rate decreases the after-tax wage. The effect on search effort depends on whether labor supply decreases or increases with the change in the wage. For positively sloped labor supply curves, the increase in the tax rate decreases search effort because the rewards to search are used less intensively. This decrease in search effort reduces the pre-tax wage rate. For the backward-bending portion of the labor supply curve, an increase in the marginal tax rate increases labor supply and search intensity. Kesselman also compares moving from a proportional income tax to a progressive income tax defined as a flat marginal tax rate but with an income grant - holding revenue constant. The 
substitution effect from the decrease in the after-tax wage unambiguously reduces search effort.

This negative effect of a progressive income tax on job search is ambiguous if the returns to search effort are uncertain. Eaton and Rosen (1980) consider effects of how taxes on human capital accumulation when the returns to investment are uncertain. Interpreting job search as a form of human capital investment, an increase in the marginal wage tax rate can affect human capital investment through two channels. First, an increase in the tax rate reduces the riskiness of human capital investment, which tends to increase human capital investment. Second, the income effect from the tax change can affect individuals' willingness to bear risk, depending on the preferences of the individuals. Eaton and Rosen show that it is possible that replacing a lump sum tax with a wage tax can increase both efficiency and human capital investment through the insurance effect of the tax. Thus, with uncertain returns, a move from a proportional income tax to a progressive income tax (defined as an income grant with a single marginal tax rate) may increase job search effort, which contradicts Kesselman's result for the certainty case.

Research on taxation and human capital formation (see, e.g., Eaton and Rosen) emphasizes the importance of considering the tax treatment of both the returns to human capital investment and the costs of the investment. A standard result in this line of inquiry is that a proportional tax will not affect human capital investment when the returns to the investment are certain if the cost of investment is deductible from the tax base, as would be the case when the cost of the investment is foregone wage income at the time of the investment. With uncertain returns, as pointed out by Eaton and Rosen, the effects of a change in the marginal tax rate are ambiguous due to the insurance effect and the effect on risk tolerance.

Progressive tax rates (i.e., marginal tax rates that increase with income) complicate the 
analysis of human capital investment. With certain returns, the after-tax cost of the investment depends on the foregone after-tax earnings, which depend on the non-linearities in the tax system and the returns depend on the increased earnings after accounting for the potential increases in marginal tax rates. Progressive tax rates typically reduce the government's share of the cost of the human capital investment and increase its share of the returns, suggesting that, relative to a constant marginal tax rate, progressive tax rates reduce the incentive for human capital investment. Uncertainty exacerbates the problem; while it may be relatively straightforward to calculate the after-tax cost of the investment, the after-tax return depends on the uncertain return on the investment. For job search, the return may be zero if the search fails to find a better job or it may be large if the search provides a substantially better job.

To fix ideas about the role of progressive tax rates, consider the following stylized example of a risk-neutral employee deciding whether to look for a new job. Abstracting from decisions over search intensity, the search decision is a discrete choice with both a tax-deductible cost (e.g., foregone wages in the current period) of $c_{D}$ and a non-tax-deductible cost of $c_{N}$. The job search is successful with a probability of $\pi$ and the search is unsuccessful with a probability of $(1-\pi)$. We assume that if the individual does not find a better job, then he or she can continue in his or her current job and earn wage income, $w_{i, t+1}$. A successful job search increases wage income by a percentage $\theta$ so that wage income increases to $(1+\theta) w_{i, t+1}$. We model jobs as yielding wage income (instead of modeling an hours choice for a fixed wage rate) to reflect salaried jobs. To capture the consequences of progressive taxation, a tax rate of $\tau$ applies to income at the level of earnings for the current job but the tax rate increases to $(1+\beta) \tau$ with $\beta>$ 
0 if the job search is successful. ${ }^{5}$ We assume a discount rate is zero to simplify the comparison of costs and benefits. We also ignore any non-monetary attributes that may vary across jobs.

Without taxes, the expected return to job search is positive if $\pi \theta w_{i, t+1}>c_{D}+c_{N}$. If the tax rate is constant (i.e., $\beta=0$ ) and all of the costs of search are tax-deductible (i.e., $c_{N}=0$ ), then the decision rule is to search for a new job if $\pi \theta w_{i, t+1}>c_{D}$, which implies that a constant tax rate would not affect the search decisions of a risk-neutral individual. ${ }^{6}$ This result differs from Kesselman's results because we do not allow for a labor market response that would affect the intensity with which the gains from search are employed (i.e., if search results in a higher wage rate, then the tax rate affects the returns to search by affecting the hours worked decision). If some of the costs of search are not tax-deductible, then the decision rule is $\pi \theta w_{i, t+1}>c_{D}+c_{N} /(1$ - $\tau$ ), so that even a proportional income tax would lower probability of job search.

Including tax progressivity, the decision rule is to search if $\pi\left[(1-\tau) \theta w_{i, t+1}-(1+\theta) \beta\right.$ $\left.\tau) w_{i, t^{+}}\right]>(1-\tau) c_{D}+c_{N}$. An increase in the degree of progressivity (i.e., a higher value of $\beta$ ) reduces the benefits of job search without affecting the cost of job search. In a sense, the appropriate "marginal" tax rate for evaluating job search incentives depends on the tax rates at all of the possible income levels that will result from job search.

This simple description of search decisions belies two prominent features of search models. First, search theory is inherently about frictions in the labor market. Without frictions,

\footnotetext{
${ }^{5}$ For tractability, the tax rate is an average tax rate. We have in mind that the average tax rate changes because marginal tax rates increase for higher levels of income rather than because of exemptions that would affect the average tax rate, but not the marginal return to job search.

${ }^{6}$ Implicitly, we are assuming that the tax-deductible costs of search do not force the individual into a lower tax bracket. If these costs are relatively large, then with a progressive tax schedule, the government would share less in the costs of job search due to the lower marginal tax rate caused by the deductions for job search. This effect would reduce the probability of job search.
} 
if skills are static, one must ask why workers have not already found a good match in the labor market. ${ }^{7}$ One possibility is that job changes are part of a larger process of human capital accumulation. By acquiring more skills (either on the job or outside of the job), a worker may feel that he or she is better prepared for an alternative job. The possibility of skills changing over time creating the need for search and job changes fits well with the framework of Eaton and Rosen discussed above because their model is based on human capital investment.

Second, the simple formulation does not account for general equilibrium effects by which the tax system might affect the wage distribution. For example, if the tax system is more progressive, the distribution of possible wage offers may adjust to compensate potential new employees for the increase in their taxes. That is, what is the tax incidence of differences in progressivity when wages are determined through a search process? To the extent that workers do not bear the burden of progressive taxes, then our empirical tests should be less likely to find effects from the tax system. As discussed below, our econometric identification comes from a combination of differences in tax incentives over time, across place, and across individuals due to personal circumstances (e.g., their location on the tax schedule). While general equilibrium effects may affect the time-series and geographical differences in progressivity, it is unlikely that they would affect the individual-specific variation.

\section{Empirical Specification and Data}

To discriminate among potential effects of tax rates on job turnover, one would ideally

\footnotetext{
${ }^{7}$ For search by the unemployed, one can appeal to stochastic events that disrupt employment spells; however, this argument does not explain on-the-job search.
} 
like to have household-level panel data, with information on employment, job changes, and sufficient information to estimate measures of income tax convexity across households and time. For a household, the relevant convexity of the income tax depends upon provisions of the tax code and a description of the ex ante distribution of payoffs to possible new jobs. While households face a common tax code, they may have access to different distributions of job opportunities. Furthermore, the marginal tax incentives for job search depend on a household's location on the tax schedule.

In this section, we begin by describing our sample selection and our measure of job turnover. We then turn to the non-tax factors for job turnover that we include in our empirical model. Finally, we discuss our methodology for measuring the tax incentives for job turnover, both in terms of the level of the tax rate and the convexity of the tax schedule.

\section{III.A. Choice of Dependent Variables and Sample Selection}

The PSID provides information on employment, household income, and household characteristics. We use data over the period from 1979-1993. While the PSID starts in 1968, we begin later because the NBER TAXSIM model (our source for creating tax variables) includes state tax code information starting in the late 1970s. We end with 1993 because it is the last year for which final-release PSID data are available. We use both the representative national sample and the sample of low-income families; our analysis uses sample weights to avoid overweighting the low-income households.

Our sample conditions on being a head of household between the ages of 18 and 60 who is in the workforce in consecutive years with positive income in year $t$. We exclude the self- 
employed (in either year) to focus on transitions from working for one employer to another. ${ }^{8}$

The sample pools single men and women (and single parents) and married heads of households (almost always men); in our sensitivity analysis, we examine whether this pooling matters. We exclude married women to avoid issues of the endogeneity of labor force participation. ${ }^{9}$ For job turnover, our sample has 38,638 observations from 7,424 distinct households. ${ }^{10}$

To focus on voluntary job changes, our main dependent variable is whether the head of household moves to a better job during the coming year. These job changes may or may not involve a change in employer. ${ }^{11}$ For the years 1979 through 1984, the PSID asks individuals who change jobs during the year whether new job is better than the old job; for years 1985 through 1992, we define "better" as a voluntary change in jobs. ${ }^{12}$ The inclusion of year effects subsumes differences in the average propensities for turnover created by using different questions in different years. In estimating the probability of changing jobs, we use explanatory (2002a).

${ }^{8}$ We analyze the decision to enter self employment in a separate paper; see Gentry and Hubbard

${ }^{9}$ The labor force participation of married women may be quite sensitive to the tax system because, in part, given their husbands' income, they face a relatively high marginal tax rate on participating in the labor force. Given the sensitivity of their participation to the tax system, employed married women simultaneously decide whether to participate and to search. Given our simple methodology for calculating the degree of tax convexity, jointly modeling these two decisions is beyond the scope of our analysis.

${ }^{10}$ In defining a "household," we classify changes in marital status as a change in the household for the individual; over time, an individual can be part of different households.

${ }^{11}$ The job turnover variable is based on the respondent having a job in year $t$ and year $t+1$ and having tenure in the year $t+1$ job of less than one year. This tenure variable is not available in the 1993 survey year. In addition creating the job change variable requires data from a subsequent survey.

12 Through 1987, the question regarding voluntary job changes is asked about changes in a worker's position (even if the employer stays the same). After 1987, the survey asks whether a change in employer is voluntary and whether the employee considers a change in a position with the same employer as a "promotion;" for these latter cases, we assume a "promotion" is a better job. 
variables from year $t$ to predict whether a head of household changes jobs during the coming year.

The main advantage of using job turnover as a measure of search activity is that it captures job changes that are not preceded by "reported" search activity. Nevertheless, job changes are an imperfect measure of ex ante job search activity because only successful job searches result in job changes. While relying on job changes as a measure of search activity obviously censors the unsuccessful searches, individuals who search harder are more likely to switch jobs so some of the censored searches are arguably less intense than the successful searches. We examine alternative measures of search behavior, including whether the head of household moves to any new job or reports searching for a new job, in our sensitivity analysis.

For our main specification, we estimate probit models of changing jobs between year $t$ and year $t+1$, TURNOVER, by the head of household $i$ during year $t+1$ :

$$
\text { TURNOVER } R_{i, t+1}=f\left(x_{i p}, z_{i}, \gamma_{t}\right)
$$

where $x_{i t}$ are job characteristics of the individual's current job, $z_{i t}$ are household characteristics, and $\gamma_{t}$ are year effects common to all households. We describe the explanatory variables in the next two subsections.

\section{III.B. Non-tax Factors Influencing Job Search}

Controlling for the job and family characteristics is important for two reasons. First, these variables may capture factors, such as job stability or attachment, that affect the decision to look for another job. Second, as we discuss below, our measure of the tax convexity that is relevant for the decision whether to look for a new job depends on many factors, including household characteristics. Controlling for these characteristics reduces the probability of our 
estimated results being driven by spurious correlations among household characteristics, tax convexity, and the job search propensity.

As job characteristics, we include dummy variables for the worker's occupation, industry (both at the two-digit classification level in the PSID), and union membership status in year $t$ and the level and square of the labor earnings of the head of household in year $t$. While the quadratic function of labor earnings controls for how current earnings affects search and turnover propensities (controlling for other demographic characteristics), the decision to look for another job may depend on current earnings relative to the earnings of similarly situated individuals. To capture relative earnings, we include the worker's percentile in the real wage earnings distribution conditional on age (grouping heads of household by decade) and education (grouping workers using the five education categories described below). To calculate this relative earnings variable, we pool observations from all years of our sample. We expect that workers with higher relative earnings will be less likely to change jobs. We also include two measures of job tenure: (1) number of years with the same employer; and (2) number of years in the same position. Job tenure may capture job attachment so it is likely to be negatively related to turnover or search. Royalty (1998) discusses the role of age and job tenure for turnover.

For household characteristics, $z$, we include the number of children in the household and dummy variables for five-year age ranges for the head, whether the head is nonwhite, female, single, a homeowner, whether the household lives in a rural area (not resident in a Standard Metropolitan Statistical Area), and whether the head experienced a marital transition during the year (using separate variables for marriages, divorces, or the death of a spouse). We approximate educational status with indicator variables for "less than high school education," 
"some college," "college," and "some post-college education" (with the omitted category being a high school education). We control for the level and square of the spouse's labor earnings in year $t$, assigning values of zero to non-married households. We also include property income and dividend and interest income as proxies for wealth, which is not available on an annual basis in the PSID. Finally, we include Census-region-specific year dummy variables to capture regional-specific effects of macroeconomic conditions; that is, we allow the year effects, $\gamma_{t}$, to vary by Census region. Table 1 provides summary statistics for the control variables.

\section{III.C. Measuring the Level of the Tax Rate}

To construct tax variables, we use the TAXSIM model of the National Bureau of Economic Research (see Feenberg and Coutts, 1993). To estimate the household's predicted future marginal tax rate, we use household characteristics in year $t$ and project the tax rate using the year $t+1$ tax code. ${ }^{13}$ From the PSID, we use household characteristics on family size, family structure, age, labor earnings, dividends, interest received, income from other sources (e.g., rental income), and state of residence..$^{14}$ To capture the effects of future wages exceeding current wages, we allow earnings to grow by five percent in constructing our benchmark tax rate. The benchmark tax rate captures the marginal incentive for effort at the current level of earnings,

\footnotetext{
${ }^{13}$ The decision to look for a new job depends on longer-run consequences rather than just income over a short horizon. We use the near-term tax code for forming tax rates because households probably have a better idea of the near-term tax structure (either explicitly or implicitly through observing the aftertax living standards of households with differing levels of success) than of the actual future tax code when the steady-state outcome will be realized.

${ }^{14}$ We restrict our analysis to PSID observations that have these data items. Actual tax returns incorporate data that are not available from the PSID. For example, without interest payments and charitable contributions, we understate the number of households that itemize their deductions. We do not have data on realized capital gains; however, because many capital gains realizations are transitory phenomena, excluding realized capital gains probably better captures the incentives to change jobs.
} 
assuming that this effort does not change the household's marginal tax rate. It also approximates the relevant marginal tax rate for deductible expenses associated with job search.

The TAXSIM model processes the PSID data by augmenting non-wage income by $\$ 100$ to calculate federal and state income tax payments and marginal income tax rates. Because the tax rate schedules can have notches, TAXSIM occasionally produces unrealistic marginal tax rates; we exclude observations for which TAXSIM produces marginal or average tax rates that are below -20 percent or above 75 percent.

\section{III.D. Measuring Tax Convexity}

In addition to measuring these job characteristics, household characteristics, and the level of the marginal tax rate, we face the more complicated task of adding empirical measures of the curvature of the tax system. While the current tax rate facing a worker is a relatively easy concept to model, the convexity of the tax system that a worker faces is much harder to measure. The model above highlights the importance of the asymmetry in the variation of tax rates. Neither the average tax rate at various outcomes nor the variance in tax rates faced over the distribution of outcomes are useful measures of the asymmetry in tax rates faced by potential job changers. Instead, we require a measure of the spread in tax rates across the distribution of possible outcomes.

To measure the curvature of the tax system, we need two types of information. First, we need information on how tax rates change with income. Second, we need information on how wages might change in the future.

For measuring features of the tax code, we again turn to the NBER TAXSIM model. Our goal is to calculate tax rates that someone who changes jobs would face at various levels of 
success. As discussed above, search theory predicts that someone will only accept a job offer if the new job is better than the old job; hence we base our measure of the relevant nonlinearities in the tax code on the distribution of wage growth conditional on wage growth being positive, which we define as a "successful job search." To compute our convexity measures, we repeat the TAXSIM tax rate calculations for alternative levels of income by replacing the head of household's labor income with some multiple of the original labor income (e.g., 110, 125, 150, 200, and 300 percent of labor income for the five levels of being successful). Comparing these tax rates with the benchmark tax rate describes the shape of the tax schedule above the worker's current level of income.

Our basic measure of tax convexity is the difference between the weighted average (using weights as derived below) of the marginal tax rates in the various successful states and the marginal tax rate in the benchmark outcome of wage growth of five percent. That is, how does the marginal tax rate change between good outcomes and the benchmark outcome? For someone facing a constant marginal tax rate over the range of possible outcomes, this measure of convexity is zero. If success changes the household's tax bracket, then the convexity measure is non-zero (and typically positive). ${ }^{15}$

To summarize the shape of the tax schedule above the current level of income, we need

\footnotetext{
${ }^{15}$ Our construction of the relevant tax convexity facing an individual depends on the household's location on the tax schedule. If households bunch just below kink points in the piecewise-linear tax schedule, then relatively small improvements in income would imply higher marginal tax rates. Saez (1999) finds support for bunching but the effect is concentrated at low levels of income. If this bunching is intentional, then one might argue that our measure of convexity is endogenous to household behavior. Alternatively, evidence on deliberate bunching would suggest that households have some information about the location of kink points, though some of this behavior might be more consistent with ex post tax reporting phenomenon rather than ex ante behavioral changes. Without deliberate bunching, the distance from a kink point is a fairly random household characteristic.
} 
to combine the tax rates calculated from TAXSIM with information about how job search will affect wage income. Some previous research provides some guidance on the potential returns to search. The work by Topel and Ward (1992) on job mobility indicates that job changes of young men are associated with an average wage increase of ten percent. ${ }^{16}$ Similarly, using stochastic frontier regression techniques, Hofler and Murphy (1992) estimate that, on average, workers earn wages that are approximately ten percent less than what they would earn if labor market information was perfect and costless.

While the previous research focuses on the average returns to job search, we need a more complete picture of the distribution of job changes since we want to use information from all five levels of possible success. To characterize how changing jobs affects a worker's relatively longterm earnings prospects, we examine the distribution of real earnings growth over a three-year period. ${ }^{17}$ This distribution does not condition on changing jobs; it merely captures the distribution in the growth of wage income. We examine heads of households that did not enter self employment between year $t$ and year $t+1$, but were in the workforce in year $t$; calculating

\footnotetext{
${ }^{16}$ One could directly examine the effect of job search or changing jobs on wage growth as indicators of the value of job search. However, conditioning on either of these variables has some disadvantages relative to just examining the overall distribution of wage growth. Conditioning on job search may select workers who perceive their current job to have low growth prospects; if their search does not yield a new job, then the low wage growth in their current job may downwardly bias the conditional distribution of wage growth relative to the distribution perceived when workers decide whether to search for a new job. Conditioning on an observed job change may conflate the effects of voluntary job changes (which tend to increase income) and involuntary job changes (which may reduce labor income). Thus it is unclear whether these conditional wage growth distributions provide better information on the distribution of job prospects than the unconditional distribution does.

${ }^{17}$ The choice of focusing on the three-year wage growth is inherently arbitrary. We use these calculations merely to illustrate what changes in income potential job changers might reasonably expect to face. A short time horizon may suffer from income being low if the worker has some time between jobs or it may be high if the worker earns extra money during the transition (e.g., suppose changing firms carries a signing bonus); however, longer horizons reduce the amount of available data. We selected three years as an attempt to balance these competing concerns.
} 
wage growth also conditions on household heads having labor income of at least $\$ 1,000$ in the first year (to avoid unreasonably large growth rates) and nonnegative labor income in year $t+3$, as well as being between the ages of 18 and 60 in the first year.

Prospects for wage growth vary considerably across workers of different ages, education, and income levels. To capture this heterogeneity, we calculate the three-year real wage growth distribution conditional on being in one of four age groups (less than 30 years old, 30-39 years old, 40-49 years old, and 50-59 years old) and one of five education groups (described above). ${ }^{18}$ Thus we calculate the earnings growth distribution for each of 20 groups of households. For each of these groups, we focus on households with positive wage growth to capture the benefits of search. In order to assign a weight to each of the five possible levels of success $(10,25,50$, 100 , and 200 percent increases in real wage income), we form a histogram for each group. The histogram calculates the percentage of households in each of five groups based on their real wage growth: (1) 0 - 15 percent, (2) 15 - 35 percent, (3) 35 - 75 percent, (4) 75 - 125 percent, and (5) greater than 125 percent. The percentage of households in each group is the weight that we use for each of our five levels of success (e.g., the fraction of households in the $0-15$ percent growth range is the weight for 10 percent wage growth). This approach provides a framework for how to weight the various outcomes above the current earnings level.

Across the 20 groups (age-by-education cells), the data imply the following average weights (the average is weighted by the number of households used in our base regression for each cell): (1) 0.421 on a 10 percent improvement; (2) 0.274 on a 25 percent improvement; (3)

\footnotetext{
${ }^{18}$ In sensitivity analysis, we explore whether the choice of the comparison group for constructing these weights affects the results.
} 
0.176 on a 50 percent improvement; (4) 0.0653 on a 100 percent improvement; and (5) 0.0648

on a 200 percent improvement. The median weights are $0.428,0.271,0.176,0.0620$, and 0.0578 , respectively.

We formulate the levels of success by examining the change in real wage income over a three-year horizon. Several comments are in order. First, these growth rates are for the entire three-year span; they are not annualized growth rates. Our assumption is that job changes are motivated by medium-term benefits rather than just the immediate impact of the job change. Second, our goal is to estimate the change in the level of wage income, not the change in the rate of growth income. (We are not claiming that a job change puts the worker on a different earnings growth profile.) By using percentage changes (as opposed to absolute dollar changes), we avoid the problem of a large absolute dollar increase for a low-income worker being a small percentage increase for a high-income worker (and vice versa). ${ }^{19}$ Third, because we are focusing which tax rates matter conditional on success, our weighting scheme conditions on positive wage growth; the unconditional wage growth is obviously considerably lower. Fourth, we also assume that other types of income and demographics do not change with the decision to change jobs. For example, the wife's labor supply does not change when her husband changes jobs.

By using growth rates, we link the distribution of job search outcomes to current income by expressing the opportunities as percentage increases in current wage income. The convexity measure assumes that each head of household within an age and education cell with a given current labor earnings has the same potential distribution of job offers. That is, other household

${ }^{19}$ A key part of our convexity measure is whether households change marginal tax rate brackets. In the early years of the sample, the tax code had many different tax brackets, but the income range within a bracket increased with income. Thus using a constant percentage variance in outcomes makes the probability of changing marginal tax brackets similar across income groups. 
characteristics do not affect the variance of the outcomes. An alternative approach would use draws from the earnings distribution conditional on characteristics such as age and education. We rejected this alternative because of the likely importance of unobservable characteristics as important determinants of wage income. Using only observable characteristics to project possible wage growth would imply that someone with high unobservable ability (so that they are near the top of the wage earnings distribution for their age and education group) would have no incentive to change jobs.

Even focusing on income taxes, measuring the convexity of the tax system is difficult. By using marginal tax rates at specific income levels, our measure focuses on the shape of the tax rate schedule over the relevant range of outcomes associated with job changes; for example, if a household remains in the same marginal tax bracket regardless of the job change, our measure of convexity will be zero. As an alternative measure of convexity, we replace our marginal tax rate measures with average tax rate measures. The level of the average tax rate replaces the level of the marginal tax rate; the spread between average tax rates for successful search and the benchmark income level replaces the marginal tax rate measure of convexity. This alternative measure of convexity incorporates features of the tax code that apply to incomes below the income associated with unsuccessful search; for example, reducing every household's tax liability (irrespective of income or employment status) by $\$ 500$ would affect average tax rates but not marginal tax rates.

Before presenting results on how convexity affects job search behavior and job turnover, some simple examples help illustrate our measure of convexity. These examples also help clarify the sources of econometric identification for the convexity effects. Consider a family 
with one child that lives in a state without a state income tax; the 35-year old husband with a high-school diploma (the age and education affect the convexity weights) earns $\$ 25,000$, and the wife earns $\$ 15,000$. In the 1986 tax code, this family faced a marginal tax rate of 28 percent and our convexity measure based on marginal tax rates for this household is 4.74 percentage points; by virtue of the reduction in tax brackets from the Tax Reform Act of 1986, such a family would face a marginal tax rate of 28 percent in 1988, but would have a convexity measure of only 0.27 percentage points. By 1992, such a family's marginal tax rate was 15 percent, and their convexity measure was 3.79 percentage points. Alternatively, consider a family in which the 35 year old husband with an advanced degree earns $\$ 90,000$, and the wife earns $\$ 50,000$. For the years $1986,1988,1992$, and 1993, such a family would face marginal tax rates of 49, 33, 31, and 31 percent, respectively; however, the convexity measure would be $0.14,-0.35,0.71$, and 3.19 percentage points, respectively. The increase in 1993 arises from the 1993 tax act that increased marginal tax rates on high-income families.

These examples reveal that convexity need not be positively correlated with the level of the tax rate or with income. Table 1 includes the basic summary statistics on the tax rate and convexity measures. The mean of the marginal tax rate spread is 2.95 percentage points and the median is 2.71 percentage points. The fifth, $25^{\text {th }}, 75^{\text {th }}$, and $95^{\text {th }}$ percentiles of the distribution of this measure of convexity are $-0.82,0.75,4.73$, and 8.05 percentage points, respectively. Figure 1 provides a histogram of the median upside convexity measure by income deciles (computed on an annual basis). Middle-income households face the most convexity; for example, the sixth income decile has a median convexity measure of 4.05 percent. While the figure indicates that convexity varies with income, convexity also varies within each income decile. For example, for 
the overall sample, the standard deviation of the convexity measure is 3.12 percentage points but within income deciles the standard deviation of the convexity measure ranges from 2.08 to 4.28 percentage points indicating that income is only one of the determinants of convexity. ${ }^{20}$ Overall, the convexity depends on tax provisions that vary across households within a state, across similar households in different states, across time, and the distribution of income within the family.

\section{Estimated Effects of the Income Tax on Job Search}

In this section, we present our empirical results, focusing on moves to better jobs. In the four subsections, we discuss (1) our base specification for all households and for married men; (2) sensitivity analysis to check the robustness of our results and inquire into the importance of different sources of econometric identification; (3) how the estimated effects vary by income, education, and age groups; and (4) alternative dependent variables based on all job changes and self-reported job search activity.

\section{IV.A. Base Specification}

Table 2 presents the results for our base specifications on the determinants of whether an employed person moves to a better job during the next year. The first two columns present results for specifications that include all households; these specifications pool single men or women and married men as heads of households. The third and fourth columns report results

\footnotetext{
${ }^{20}$ To get a sense of the variation within subgroups of the sample, as opposed to variation across groups, consider the percentage of the variation in convexity explained by grouping the data. Income decile effects, year effects for each Census region, and state effects explain 6.8, 7.3, and 0.9 percent, respectively, of the variation in convexity. Simultaneously controlling for these three characteristics explains 15.0 percent of the variation in convexity.
} 
restricting the sample to married men. Focusing on married men removes the possibility that tax convexity differs between married and single households because they file different tax returns; this difference could create spurious results if these differences in convexity were correlated with different propensities of single and married people to change jobs. For each sample, we present results that use the convexity measure based on marginal tax rates and the convexity measure based on average tax rates.

The first column of Table 2 presents results using the marginal tax rate measures of the tax variables. The estimated coefficient on the level of the tax rate of -0.00158 is statistically different than zero at the 99 percent confidence level. A five-percentage-point reduction in the marginal tax rate increases the probability of moving to a better job by 0.79 percentage points. Given that the average propensity to move to a better job is 0.0987 (i.e., 9.87 percent), this increase represents a 8.00 percent increase in the likelihood of job movement.

The estimated coefficient on the convexity of the tax system of -0.00277 is statistically different from zero at the 99 percent confidence level. In terms of economic significance, this estimate implies that a one-standard-deviation reduction in the marginal tax convexity measure (3.12 percentage points) would increase the turnover propensity by 0.86 percentage points. The average turnover propensity is 9.87 percent, so this effect is a 8.71 percent increase in probability of moving to a better job. These estimates suggest that the tax system affects job mobility, with high tax rates and progressive tax rates reducing mobility.

The second column of Table 2 presents the results for the average tax rate measures of the tax variables for all households. The estimated coefficient on the level of the tax rate is -0.00178 , and the estimated coefficient on the average tax rate convexity measure is -0.00617 ; 
both estimated coefficients are statistically different from zero at the 99 percent confidence level. The point estimates are larger when using the average tax rate measure of convexity; however, because the average tax rate measure has a lower standard deviation, the estimated effect of a one-standard-deviation reduction (1.23 percentage points compared to 3.12 percentage points) in convexity implies a slightly smaller effect on the expected rate of moving to a better job. A onestandard-deviation reduction in the average tax convexity measure would increase the probability of a job change by 0.76 percentage points, or 7.69 percent of the average turnover propensity.

The results from focusing on married men are similar to those reported for the overall sample, except that the point estimates are roughly 15 percent larger in size; the estimated effects are statistically different from zero at the 99 percent confidence level. ${ }^{21}$ For the sample of married men, a five-percentage-point reduction in the level of the marginal tax rate is predicted to increase the rate of movement to a better job by 0.92 percentage points, which is a 11.25 percent increase in the turnover propensity of married men (which is 8.18 percent). In terms of the convexity effect, a 3.12 percentage point reduction in convexity would increase the average propensity to move to a better job by 1.00 percentage points, which is a 12.47 percent increase in the average turnover propensity. Using the average tax measure of convexity implies larger estimated effects of both the level of the tax rate and tax convexity on job mobility.

In terms of the other variables, the most important explanatory variables are associated with increased job attachment - union membership, job tenure, and age. Based on the results in

${ }^{21}$ The similarity between estimates based on all households and those based on married men extends throughout the various robustness checks presented below; hence, to conserve space, we focus on the sample with all households for the remainder of the paper. 
the first column, union members are 1.75 percentage points less likely to move to a better job and an increase in job tenure by one year reduces the probability of moving to a better job by 0.40 percentage points. The (unreported) estimated effects of the various age ranges confirm that younger workers are more likely to change jobs. Education beyond high school is positively correlated with the search propensity; the partial effects of education variables should be interpreted with caution because the regression also controls for occupation and industry. Conditional on other characteristics, the estimated effects of the income variables - wage earnings of the head and spouse, capital income, and the dummy variables for the real wage quintile - suggest only a modest statistical relationship between current income and the propensity to move to a better job.

\section{IV.B. Sensitivity Analysis and the Sources of Econometric Identification}

A number of statistical issues merit further investigation. First, interstate variation in income taxes is one source of econometric identification in our base specification. It is possible that this variation in income taxes is correlated with other, omitted interstate variation in the search environment across states. Including state fixed effects removes the average timeinvariant state-specific component to the search environment (but still allows intertemporal differences in state tax policy and cross-sectional intrastate variation in tax incentives to affect the estimated coefficients on the tax variables). Including state fixed effects to the specifications reported in Table 2 increases the magnitude (and associated statistical significance) of the estimated coefficients on both the level of the tax rate and tax convexity relative to the results without state fixed effects by roughly 20 percent. Thus it seems unlikely that the results in Table 2 are an artifact of spurious correlation with omitted state-specific characteristics of the job 
search environment.

Second, the intertemporal variation in income tax provisions is another source of variation that we use to identify the model. To examine the importance of intertemporal variation in tax incentives as a source of econometric identification, we estimate specifications of the first and third columns of Table 2 that allow the estimated tax effects to vary by year. For these specifications econometric identification comes from differences in location on each year's tax schedule from both the head's earnings and other family-specific information (e.g., spousal income) and in the variation in state tax policy. We find no strong pattern in the estimated effects of the level of the tax rate. While the majority of the estimates of the convexity effect are negative, statistical significance is limited. Thus pooling the years is important for estimating the effects of convexity; however, this pooling may be important either because it increases the sample size or because it increases the variation in tax incentives.

Third, a common statistical problem in estimating the effects of tax policy is that the parameters of the tax system are correlated with income. Thus it is difficult to disentangle the effects of the tax system from non-linearities in income effects. This problem is especially severe for the level of the tax rate because tax rates have a direct relationship with income. We expect the problem to be less severe for the convexity effect because convexity is not a simple function of income. Nonetheless, we examine the importance of how we control for income in two ways. First, we estimate models with alternative functional forms for earnings controls. Second, we estimate the model with interactions between the tax parameters and a household's income quintile in the year of the observation. This second method attempts to identify the tax effects using the variation in the tax incentives for families within the same income quintile 
without using the variation across different parts of the income distribution.

Table 3 provides results for estimating the job search probits for four alternative methods of controlling for labor income of the household head and the spouse. The four columns of the table correspond to: (1) using linear terms in the earnings of the husband and wife; (2) including a cubic function of labor earnings of the husband and wife; (3) using the logarithms of labor earnings; and (4) a quadratic function of earnings supplemented with dummy variables for the household's income decile formed from annual data. Across the board, the estimated effects of both the level of the tax rate and tax convexity are negative and statistically different from zero at the 99 percent confidence level. The point estimates, albeit smaller than those reported in Table 2, are typically quite similar to those found using a quadratic function of earnings.

Overall, these alternative specifications indicate that the results are not sensitive to the functional form of the earnings control, suggesting that the results are not driven by a spurious relationship between job turnover patterns, income, and the shape of the tax schedule.

One further area of to explore is how our chosen method of choosing the weights for our tax convexity measure affects the results. Recall that in our base specification the weights for the various positive outcomes from a job change vary across 20 groups, depending on the age and education level of the head of household. As alternative conventions for choosing the weights on different levels of success, we recalculate the histograms for three-year real wage growth conditioning on different groups of the population. We use five alternative conventions: (1) all households so that the weights are the same for all individuals; (2) weights that vary across the four different age groups; (3) weights that vary across the five education groups; (4) weights that vary across quintiles in the distribution of real wage income; and (5) weights that 
vary by quintiles in the distribution of wage income that are constructed conditional on the age and education cell for the head of household (100 groups in all).

Table 4 reports the estimated effects of the tax variables for these five alternative weighting schemes. The results indicate that the first three weighting schemes lead to similar estimates for the level of the tax rate and slightly larger estimated effects of convexity (compared to the first column of Table 2). Using the wage quintile weights reduces the size of the estimated effects, but the estimated coefficients remain statistically different from zero at the 99 percent confidence level.

The results in the last column, in which the weights are based on the head's wage income quintile conditional on his or her age and education, are somewhat different than the other cases. The estimated effect of the level of the tax rate drops to -0.00101 , and the estimated convexity effect drops to -0.000192 (one-tenth the size of the previous estimates), and it is no longer statistically significant. One problem with the convention used in the last column is that some of the weights are formed using relatively small samples of individuals (e.g., fewer than 50) which leads to some weighting schemes that are implausible. ${ }^{22}$ While we cannot rule out that the weighting scheme affects our results, reasonable choices on dimensions along which to allow the weights to vary lead to similar results to our base case. Thus we conclude that our results are do not simply represent a chance relationship based on our choice of weights for different levels of success.

${ }^{22}$ For example, the maximum weight on a 200 percent increase in wage income is 0.59 , which is almost four times larger than the maximum weight on such an increase in our base case, and the minimum weight on the smallest increase ( 10 percent) is 0.017 , compared to a minimum weight of 0.239 in our base case. 


\section{IV.C. Estimated Effects within Income, Education, and Age Groups}

The first panel of Table 5 presents an alternative identification strategy that focuses on the variation in tax incentives within each income quintile by allowing the estimated tax effects vary by income quintile. The specification controls for labor earnings using a quadratic specification and the other variables included in the main specification. The estimated effects of both the level of the tax rate and tax convexity on job changes are negative for all five income groups. ${ }^{23}$ However, statistically significant estimates are concentrated among the top two income quintiles. The size of the estimated effect of convexity increases with income, which suggests the sensitivity to nonlinear labor market payoffs may increase with income. In terms of determining the source of econometric identification, the negative effects within income quintiles suggest that the overall negative effect may not be driven by a spurious correlation between tax convexity and income; however, given the relatively low statistical significance for some of the coefficients, one cannot draw definitive conclusions from this test.

The second and third panels of Table 5 provide estimates for the tax effects within education and age groups, respectively. These specifications test whether the tax effects are concentrated among particular demographic groups. Again, for both the level of the tax rate and tax convexity, the estimated coefficients are uniformly negative. For the level of the tax rate, there is no discernable pattern in the estimated effects in either panel of the Table. For convexity, the estimated effecs are larger for better educated groups and when the head of the

\footnotetext{
${ }^{23} \mathrm{We}$ find similar results if we define the income quintiles using wage earnings of the head of household conditional on the age and education cell of the head of household. By conditioning on age and education, this alternative classification defines "low" or "high" earnings compared to people with similar backgrounds. The advantage of using family income is that family income is the relevant variable for determining the household's location on the tax schedule.
} 
household is under age 40 .

IV.D. Alternative Dependent Variables Based on All Job Changes and Job Search Activity

Our analysis thus far has focused on transitions to a better job. These are the transitions for which the upside tax convexity is most likely to have a negative effect. For example, voluntary moves to a lower-paying job (e.g., in order to work fewer hours) will not result in the worker incurring the costs of paying higher tax rates. Involuntary separations will lead to search from unemployment. Indeed, it is less clear how critical the income tax incentives will be for the job decisions of the unemployed, especially if the worker can take a new job and continue to search for a better job, and our tax variables based on current employment may be not precisely capture the relevant features of the tax code for the unemployed. Despite these arguments to focus on transitions to a better job, one would like to know whether the results are sensitive to this choice of dependent variable.

Table 6 presents the results of probit regressions using two alternative dependent variables: (1) whether the head of household changes jobs during year $t+1$; and (2) whether the head of household reports actively looking for another job at the time of the year $t$ interview. The first measure includes all job changes, including those that result from an involuntary separation. The second measure uses self-reported information on search activity.

The first two columns report the results for examining all job changes for all households and for married men, respectively, using the tax measures based on marginal tax rates. The point estimates of the tax variables are larger in absolute value using the alternative definition of job changes (by about 70 percent for the level of the tax rate and 50 percent for the convexity variable). While the estimated effects remain statistically significant, the standard errors of the 
estimates are larger, consistent with the alternative definition of job changes being a noisier measure of job changes related to incentives to increase income.

In addition to asking job details, the PSID asks whether currently employed individuals are looking for a new job. ${ }^{24}$ These questions provide an alternative measure of job search and job mobility. One potential problem with survey responses to job search questions is that it is difficult to measure the intensity with which someone is searching. Also, these questions focus on a narrow amount of time. We estimate probit models for job search activity (defined as reporting some effort in a recent job search), SEARCH, by the head of household $i$ at time $t$ :

$$
\operatorname{SEARCH} H_{i, t}=f\left(x_{i}, z_{i}, \gamma_{t}\right)
$$

in which the explanatory variables are defined as in the turnover regression. Unlike the turnover regression, $S E A R C H_{i, t}$ refers to search at the time of the survey, which presumably leads to a job change in the coming year.

The third and fourth columns of Table 6 report the results for the job search regressions. Neither the level of the tax rate nor the convexity of the tax schedule affects whether an individual reports searching for a new job while still employed at his or her current job. The types of sensitivity analysis explored above for moves to better jobs provides some clues why the effects of taxes on job search differ from the effects on job changes. The estimated coefficients for the tax variables in the job search regressions are more sensitive to the functional

\footnotetext{
${ }^{24}$ The precise PSID questions on job search vary over the sample period. Between 1979 and 1987, the questions were: "Have you been thinking about getting a new job, or will you keep the job you have now?" and "Have you been doing anything in particular about it?". From 1988 to 1993, the first question was: "Have you been looking for another job during the past four weeks?". In these years, the follow up question was: "What have you been doing in the last four weeks to find another job?". This question was followed by a number of specific questions about activities, such as checking with current employer or checking with an employment agency.
} 
form of the earnings controls, especially the inclusion of wage quintiles conditional on ageeducation cell, than are the estimated coefficients for job changes. ${ }^{25}$ Overall, while tax incentives are related to job changes regardless of how we define job changes, we find little evidence of a tax effect on self-reported job search.

\section{Conclusion}

This paper examines the effects of income taxes - both the level of the tax rate and the convexity of the tax schedule - on job changes. We find that individuals respond to differences in both the level of the tax rate and the convexity of the tax schedule. We estimate that a fivepercentage-point reduction in the marginal rate at a worker's benchmark level of income increases the probability of moving to a better job by 0.79 percentage points (a 8.0 percent increase in the probability), and a 3.12 percentage point (i.e., a one-standard-deviation) decrease in our measure of convexity would increase the probability of moving to a better job by 0.86 percentage points (a 8.7 percent increase in the probability). For married men, these effects are slightly larger.

The effects of the convexity of the tax system on individual behavior are consistent with the findings of our work on the effects of the tax system on entry into entrepreneurship (Gentry and Hubbard, 2002a) and wage growth (Gentry and Hubbard, 2002b). For entry into

\footnotetext{
${ }^{25}$ For example, without the dummy variables for the head of household's wage quintile conditional on age and education, the estimated coefficient on tax convexity is -0.00102 and is statistically different from zero at the 95 percent confidence level. For job changes, the estimated coefficients on these dummy variables are close to zero and not statistically significant. In contrast, we find a strong, statistically significant pattern between job search and the individual's wage income relative to that of individuals with a similar age and education; individuals with relatively low income are considerably more likely to report looking to change jobs than are relatively well paid individuals.
} 
entrepreneurship, arguably a much riskier decision with a broader spectrum of possible outcomes, we find that the convexity of the tax system has a relatively large, negative effect on the entry probability. Our work on wage growth is more closely related to job changes. While job changes are an observable labor market outcome, many other types of labor market effort are unobservable. We take the three-year real growth rate in wage income as a proxy for the cumulative effects of these various sorts of labor market effort. Consistent with our job turnover results, we find that a one-percentage-point decrease in upside tax convexity increases the threeyear real growth rate in wages from 9.1 percent to 10.5 percent (a 15 percent increase).

Our results suggest an avenue, beyond the effects of marginal tax rate on the next dollar of income, by which income tax policy can affect individual behavior. A substantial body of research, to which we referred in the introduction, has focused on the elasticity of taxable income with respect to changes in the marginal tax rate. We contribute to this research program by suggesting that the measurement of the appropriate marginal tax rate for some types of behavior may incorporate elements of the tax schedule (e.g., marginal tax rates) other than the marginal tax rate at an initial income level. One possible direction for future analysis is to integrate the effects of tax convexity more directly into the elasticity of taxable income literature. The added complications of behavior that responds to tax rates over a broad spectrum of incomes also raises issues in calculating the deadweight loss of the tax system.

Our emphasis on the effects of nonlinearities in the tax system on behavior is consistent with labor market theories that nonlinear payoffs affect the effort decisions of individuals. When individuals keep a larger fraction of the rewards to a better job match, they are more likely to move to a better, higher-paying job. 


\section{References}

Anderson, Patricia M., and Bruce D. Meyer. "Unemployment Insurance Takeup Rates and the After-tax Value of Benefits." Quarterly Journal of Economics, 112:3, 1997, pp. 913937.

Auten, Gerald, and Robert Carroll. "The Effect of Income Taxes on Household Income." Review of Economics and Statistics, 1999, 81:4, pp. 681-693.

Blau, David M., and Philip K. Robins. "Job Search Outcomes for the Employed and Unemployed.” Journal of Political Economy, 1990, 98, pp. 637-655.

Dick, Andrew W., and Aaron S. Edlin. "The Implicit Taxes from College Financial Aid." Journal of Public Economics, 65:3, September 1997, pp. 295-322.

Domar, Evsey, and Richard Musgrave. "Effects of Proportional Taxes on Risk-Taking." Quarterly Journal of Economics, 59, 1944.

Eaton, Jonathan, and Harvey S. Rosen. "Taxation, Human Capital, and Uncertainty." American Economic Review, 70:4, September 1980, pp. 705-715.

Feenberg, Daniel, and Elisabeth Coutts. “An Introduction to the TAXSIM Model.” Journal of Policy Analysis and Management, 12, 1993, pp.189-194.

Feldstein, Martin. "College Scholarship Rules and Private Saving," American Economic Review, 85:3, June 1995a, pp. 552-566.

Feldstein, Martin. "The Effect of Marginal Tax Rates on Taxable Income: A Panel Study of the 1986 Tax Reform Act." Journal of Political Economy, 103(3), June 1995b, pp. 551572.

Gentry, William M., and R. Glenn Hubbard. "Tax Policy and Entry into Entrepreneurship." Mimeograph, Columbia University, July 2002a.

Gentry, William M., and R. Glenn Hubbard. "Taxes and Wage Growth.” Mimeograph, Columbia University, January 2002 b.

Gruber, Jonathan, and Emmanuel Saez. "The Elasticity of Taxable Income: Evidence and Implications." Working Paper No. 7512, National Bureau of Economic Research, January 2000.

Gruber, Jonathan, and Aaron Yelowitz. "Public Health Insurance and Private Savings." Journal of Political Economy, 107(6), Part 1 December 1999, pp. 1249-1274. 
Hausman, Jerry A. "Taxes and Labor Supply.” In Alan J. Auerbach and Martin Feldstein, eds., The Handbook of Public Economics, New York: North Holland, 1985.

Himmelberg, Charles P., and R. Glenn Hubbard. "Incentive Pay and the Market for CEOs: An Analysis of Pay-Performance Sensitivity.” Mimeograph, Columbia University, 2000.

Hofler, Richard A., and Kevin J. Murphy. "Underpaid and Overworked: Measuring the Effect of Imperfect Information on Wages.” Economic Inquiry, 30, July 1992, pp. 511529.

Homstrom, Bengt, and Paul Milgrom. "Aggregation and Linearity in the Provision of Intertemporal Incentives.” Econometrica, 55, March 1987, 303-328.

Hubbard, R. Glenn, Jonathan Skinner, and Stephen P. Zeldes. "Precautionary Saving and Social Insurance.” Journal of Political Economy, 103:2, April 1995, pp. 360-399.

Kesselman, Jonathan R. "Tax Effects on Job Search, Training, and Work Effort." Journal of Public Economics, 1976, 6, pp. 255-272.

Lazear, Edward P. "Performance Pay and Productivity." American Economic Review, 90:5, 2000, pp. 1346-1361.

Ljungqvist, Lars and Thomas J. Sargent. "The Swedish Unemployment Experience." European Economic Review, 1995, 39, pp. 1043-1070.

Manning, Alan. "Labour Supply, Search and Taxes." Journal of Public Economics, 2001, $80: 3$, pp. 409-434.

Meyer, Bruce D. "Unemployment Insurance and Unemployment Spells." Econometrica, 1990, 58:4, pp. 757-782.

Mortensen, Dale T. “Job Search and Labor Market Analysis.” In Orley Ashenfelter and Richard Layard, eds., The Handbook of Labor Economics, vol. 2, New York: North Holland, 1986.

Mortensen, Dale T., and Christopher A. Pissarides. "New Developments in Models of Search in the Labor Market." In Orley Ashenfelter and David Card, eds., The Handbook of Labor Economics, vol. 3, New York:; North Holland, 1999.

Pissarides, Christopher A. "Efficiency Aspects of the Financing of Unemployment Insurances and Other Government Expenditure." Review of Economic Studies, 1983, 50, 57-69.

Pissarides, Christopher A. “The Impact of Employment Tax Cuts on Unemployment Benefits and Wages: The Role of Unemployment Benefits and Tax Structure." European 
Economic Review, 1998, 42, pp. 155-183.

Pissarides, Christopher A. Equilibrium Unemployment Theory. MIT Press: Cambridge, 2000.

Pissarides, Christopher A., and Jonathan Wadsworth. "On-the-job Search: Some Empirical Evidence from Britain.” European Economic Review, 1994, 38, pp. 385-401.

Poterba, James M. "Taxation, Risk-taking, and Household Portfolio Behavior." Working Paper No. 8340, National Bureau of Economic Research, June 2001.

Prendergast, Canice. “The Provision of Incentives in Firms.” Journal of Economic Literature, 1999, 37:1, pp. 7-63.

Royalty, Anne Beeson. "Job-to-Job and Job-to-Nonemployment Turnover by Gender and Education Level." Journal of Labor Economics, 1998, 16, pp. 392-443.

Saez, Emmanuel. "Do Taxpayers Bunch at Kink Points?” Working Paper No. 7366, National Bureau of Economic Research, September 1999.

Topel, Robert H., and Michael P. Ward. "Job Mobility and the Careers of Young Men." Quarterly Journal of Economics, 1992, 107:2, pp. 439-479. 


\begin{tabular}{|l|c|c|c|c|}
\hline \multicolumn{5}{|c|}{ Table 1: Summary Statistics } \\
\hline & Mean & $\begin{array}{c}\text { Standard } \\
\text { Deviation }\end{array}$ & Minimum & Maximum \\
\hline Job turnover to a better job & 0.0987 & 0.298 & 0 & 1 \\
\hline Job turnover to any new job & 0.194 & 0.396 & 0 & 1 \\
\hline Job search & 0.0798 & 0.271 & 0 & 1 \\
\hline Marginal tax rate & 29.17 & 10.16 & -19.86 & 69.45 \\
\hline $\begin{array}{l}\text { Marginal tax rate convexity } \\
\text { measure }\end{array}$ & 2.95 & 3.12 & -14.78 & 26.31 \\
\hline Average tax rate & 15.83 & 8.11 & -19.89 & 70.71 \\
\hline $\begin{array}{l}\text { Average tax rate convexity } \\
\text { measure }\end{array}$ & 2.71 & 1.23 & -29.15 & 45.84 \\
\hline Head's labor earnings & $26,108.62$ & $19,478.05$ & 50.00 & 550,000 \\
\hline Spouse's labor earnings & $5,782.34$ & $9,825.38$ & 0 & 187,500 \\
\hline Dividend and interest income & 776.34 & $2,937.09$ & 0 & 145,000 \\
\hline Other property income & 625.76 & $4,274.74$ & $-111,000$ & 250,000 \\
\hline Age & 37.75 & 10.77 & 18 & 60 \\
\hline Minority (non-white $=1)$ & 0.143 & 0.350 & 0 & 1 \\
\hline Female head & 0.229 & 0.420 & 0 & 1 \\
\hline Married (single =1) & 0.394 & 0.489 & 0 & 1 \\
\hline Number of kids & 0.937 & 1.15 & 0 & 9 \\
\hline Job tenure (in years) & 5.87 & 6.68 & 0 & 31.5 \\
\hline Union Member & 0.263 & 0.440 & 0 & 1 \\
\hline Homeowner & 0.612 & .487 & 0 & 1 \\
\hline Rural & 0.385 & 0.487 & 0 & 1 \\
\hline Less than high school & 0.152 & 0.359 & 0 & 1 \\
\hline High school & 0.376 & 0.484 & 0 & 1 \\
\hline Some college & 0.207 & 0.405 & 0 & 1 \\
\hline College & 0.187 & 0.390 & 0 & 1 \\
\hline Some post-college education & 0.0787 & 0.269 & 0 & 1 \\
\hline
\end{tabular}

Source: Authors' calculations based on data from the PSID. Our sample pools data from 1979 to 1993. The number of observations is 38,638 , except for job turnover that has 41,632 observations. The sample includes households for which the head works for someone else in year $t$ and is not out of the labor force in $t+1$. We include only those households whose age is between 18 and 60 and whose labor income is positive in $t$. We drop all observations with average or marginal tax rates larger than 75 percent or smaller than -20 percent. We also drop observations with average or marginal tax rates for the successful or the unsuccessful case larger than 75 percent or smaller than -20 percent. The sample is weighted to reflect oversampling of low-income households. 


\begin{tabular}{|c|c|c|c|c|}
\hline & \multicolumn{2}{|c|}{ All Households } & \multicolumn{2}{|c|}{ Married Men } \\
\hline & $\begin{array}{l}\text { (1): Marginal tax } \\
\text { rate measure of } \\
\text { convexity }\end{array}$ & $\begin{array}{l}\text { (2): Average tax } \\
\text { rate measure of } \\
\text { convexity }\end{array}$ & $\begin{array}{l}\text { (3): Marginal tax } \\
\text { rate measure of } \\
\text { convexity }\end{array}$ & $\begin{array}{l}\text { (4): Average tax } \\
\text { rate measure of } \\
\text { convexity }\end{array}$ \\
\hline $\begin{array}{l}\text { Tax rate on } \\
\text { employment }\end{array}$ & $\begin{array}{c}-0.00158 \\
(0.000324)\end{array}$ & $\begin{array}{c}-0.00178 \\
(0.000481)\end{array}$ & $\begin{array}{c}-0.00184 \\
(0.000373)\end{array}$ & $\begin{array}{c}-0.00239 \\
(0.000555)\end{array}$ \\
\hline $\begin{array}{l}\text { Convexity in tax rate } \\
\text { (spread) }\end{array}$ & $\begin{array}{c}-0.00277 \\
(0.000701)\end{array}$ & $\begin{array}{l}-0.00617 \\
(0.00199)\end{array}$ & $\begin{array}{c}-0.00322 \\
(0.000781)\end{array}$ & $\begin{array}{l}-0.00829 \\
(0.00223)\end{array}$ \\
\hline Head's labor earnings & $\begin{array}{c}4.29 \\
(2.87)\end{array}$ & $\begin{array}{c}5.92 \\
(2.94)\end{array}$ & $\begin{array}{c}5.58 \\
(2.49) \\
\end{array}$ & $\begin{array}{c}7.95 \\
(2.69)\end{array}$ \\
\hline $\begin{array}{l}\text { Head's labor earnings } \\
\text { squared }\end{array}$ & $\begin{array}{l}-0.877 \\
(0.717)\end{array}$ & $\begin{array}{l}-1.13 \\
(0.759)\end{array}$ & $\begin{array}{l}-1.03 \\
(0.532)\end{array}$ & $\begin{array}{c}-1.42 \\
(0.580)\end{array}$ \\
\hline $\begin{array}{l}\text { Spouse's labor } \\
\text { earnings }\end{array}$ & $\begin{array}{c}7.53 \\
(3.37) \\
\end{array}$ & $\begin{array}{c}5.26 \\
(3.50) \\
\end{array}$ & $\begin{array}{l}11.60 \\
(4.00)\end{array}$ & $\begin{array}{c}9.36 \\
(4.07) \\
\end{array}$ \\
\hline $\begin{array}{l}\text { Spouse's labor } \\
\text { earnings squared }\end{array}$ & $\begin{array}{l}-7.87 \\
(5.77)\end{array}$ & $\begin{array}{l}-4.36 \\
(5.54)\end{array}$ & $\begin{array}{l}-18.60 \\
(8.13)\end{array}$ & $\begin{array}{l}-14.10 \\
(7.48)\end{array}$ \\
\hline $\begin{array}{l}\text { Dividend and interest } \\
\text { income }\end{array}$ & $\begin{array}{c}0.979 \\
(0.692)\end{array}$ & $\begin{array}{c}0.964 \\
(0.698) \\
\end{array}$ & $\begin{array}{c}0.973 \\
(0.608)\end{array}$ & $\begin{array}{c}1.04 \\
(0.621)\end{array}$ \\
\hline $\begin{array}{l}\text { Other property } \\
\text { income }\end{array}$ & $\begin{array}{l}-0.478 \\
(0.463)\end{array}$ & $\begin{array}{l}-0.511 \\
(0.483)\end{array}$ & $\begin{array}{l}-0.245 \\
(0.380)\end{array}$ & $\begin{array}{l}-0.279 \\
(0.404)\end{array}$ \\
\hline Job tenure & $\begin{array}{l}-0.00402 \\
(0.00042)\end{array}$ & $\begin{array}{c}-0.00404 \\
(0.000420)\end{array}$ & $\begin{array}{c}-0.00193 \\
(0.000390)\end{array}$ & $\begin{array}{c}-0.00292 \\
(0.000391)\end{array}$ \\
\hline Union member & $\begin{array}{c}-0.0175 \\
(0.00448)\end{array}$ & $\begin{array}{c}-0.0176 \\
(0.0 .0448)\end{array}$ & $\begin{array}{c}-0.0140 \\
(0.00462)\end{array}$ & $\begin{array}{c}-0.0142 \\
(0.00461)\end{array}$ \\
\hline Female head & $\begin{array}{c}0.00811 \\
(0.00702)\end{array}$ & $\begin{array}{c}0.00806 \\
(0.00709)\end{array}$ & & \\
\hline Single $($ single $=1)$ & $\begin{array}{c}0.0105 \\
(0.00586)\end{array}$ & $\begin{array}{c}0.0119 \\
(0.00596)\end{array}$ & & \\
\hline Less than high school & $\begin{array}{c}0.00121 \\
(0.00615)\end{array}$ & $\begin{array}{c}0.00347 \\
(0.00627)\end{array}$ & $\begin{array}{c}0.00662 \\
(0.00654)\end{array}$ & $\begin{array}{c}0.00888 \\
(0.00672)\end{array}$ \\
\hline Some college & $\begin{array}{c}0.0162 \\
(0.00547)\end{array}$ & $\begin{array}{c}0.0164 \\
(0.00554)\end{array}$ & $\begin{array}{c}0.0128 \\
(0.00584)\end{array}$ & $\begin{array}{c}0.0136 \\
(0.00592)\end{array}$ \\
\hline College & $\begin{array}{c}0.0152 \\
(0.00788)\end{array}$ & $\begin{array}{c}0.0142 \\
(0.00788)\end{array}$ & $\begin{array}{c}0.00948 \\
(0.00807)\end{array}$ & $\begin{array}{c}0.00935 \\
(0.00812)\end{array}$ \\
\hline $\begin{array}{l}\text { Some post-college } \\
\text { education }\end{array}$ & $\begin{array}{c}0.0307 \\
(0.0110)\end{array}$ & $\begin{array}{c}0.0309 \\
(0.0111)\end{array}$ & $\begin{array}{c}0.0285 \\
(0.0117) \\
\end{array}$ & $\begin{array}{c}0.0298 \\
(0.0119)\end{array}$ \\
\hline Number of obs. & 38,638 & 38,638 & 25,241 & 25,241 \\
\hline Pseudo-R ${ }^{2}$ & 10.73 & 10.69 & 10.88 & 10.88 \\
\hline
\end{tabular}

Source: Authors' calculations, as described in the text. Estimated models include census-region effects by year, number of children, age dummies for five-year age ranges for the head of household, dummy variables for wage-income quintile conditional on age-education cell, homeowners, minority status, marital transitions, and rural residents. Table 1 lists other sample restrictions. The estimated coefficients and standard errors for labor earnings are multiplied by $10^{7}$ and for labor earnings squared are multiplied by $10^{12}$. The estimated coefficients and standard errors for capital income and property income are multiplied by $10^{6}$. The marginal effects are evaluated at the mean values of the variables; for the dichotomous variables, marginal effects are for changes from zero to one. Robust standard errors, clustered by household, are in parentheses. The regressions are weighted by sample weights. 


\begin{tabular}{|c|c|c|c|c|}
\hline & $\begin{array}{l}\text { (1): Linear } \\
\text { earnings } \\
\text { controls }\end{array}$ & $\begin{array}{l}\text { (2): Cubic } \\
\text { earnings } \\
\text { controls }\end{array}$ & $\begin{array}{l}\text { (3): Log } \\
\text { earnings } \\
\text { controls }\end{array}$ & $\begin{array}{l}\text { (4): Income } \\
\text { decile controls }\end{array}$ \\
\hline $\begin{array}{l}\text { Tax rate on } \\
\text { employment }\end{array}$ & $\begin{array}{c}-0.00149 \\
(0.000316)\end{array}$ & $\begin{array}{c}-0.00157 \\
(0.000337)\end{array}$ & $\begin{array}{c}-0.00118 \\
(0.000370)\end{array}$ & $\begin{array}{l}-0.00145 \\
(0.000349)\end{array}$ \\
\hline $\begin{array}{l}\text { Upside tax rate } \\
\text { convexity }\end{array}$ & $\begin{array}{c}-0.00274 \\
(0.000700)\end{array}$ & $\begin{array}{c}-0.00272 \\
(0.000707)\end{array}$ & $\begin{array}{l}-0.00253 \\
(0.000741)\end{array}$ & $\begin{array}{c}-0.00266 \\
(0.000728)\end{array}$ \\
\hline Head's labor earnings & $\begin{array}{c}1.63 \\
(1.29)\end{array}$ & $\begin{array}{c}5.68 \\
(5.37)\end{array}$ & & $\begin{array}{c}5.64 \\
(3.08)\end{array}$ \\
\hline $\begin{array}{l}\text { Head's labor earnings } \\
\text { squared }\end{array}$ & & $\begin{array}{l}-2.12 \\
(3.67)\end{array}$ & & $\begin{array}{l}-1.20 \\
(0.853)\end{array}$ \\
\hline $\begin{array}{l}\text { Head's labor earnings } \\
\text { cubed }\end{array}$ & & $\begin{array}{c}2.17 \\
(5.30)\end{array}$ & & \\
\hline $\begin{array}{l}\text { Log (Head's labor } \\
\text { earnings) }\end{array}$ & & & $\begin{array}{l}-0.00921 \\
(0.00657)\end{array}$ & \\
\hline $\begin{array}{l}\begin{array}{l}\text { Spouse's labor } \\
\text { earnings }\end{array} \\
\end{array}$ & $\begin{array}{c}4.46 \\
(2.17) \\
\end{array}$ & $\begin{array}{l}-9.29 \\
(7.67) \\
\end{array}$ & & $\begin{array}{l}11.30 \\
(4.01)\end{array}$ \\
\hline $\begin{array}{l}\text { Spouse's labor } \\
\text { earnings squared }\end{array}$ & & $\begin{array}{c}93.40 \\
(42.50)\end{array}$ & & $\begin{array}{l}-11.90 \\
(6.67)\end{array}$ \\
\hline $\begin{array}{l}\text { Spouse's labor } \\
\text { earnings cubed }\end{array}$ & & $\begin{array}{l}-1,130.0 \\
(577.0)\end{array}$ & & \\
\hline $\begin{array}{l}\text { Log (Spouse's labor } \\
\text { earnings) }\end{array}$ & & & $\begin{array}{c}0.000616 \\
(0.000478)\end{array}$ & \\
\hline $\begin{array}{l}\text { Dividend and interest } \\
\text { income }\end{array}$ & $\begin{array}{c}0.962 \\
(0.695)\end{array}$ & $\begin{array}{c}0.943 \\
(0.694)\end{array}$ & $\begin{array}{c}1.14 \\
(0.667)\end{array}$ & $\begin{array}{c}1.07 \\
(0.690)\end{array}$ \\
\hline $\begin{array}{l}\text { Other property } \\
\text { income }\end{array}$ & $\begin{array}{l}-0.496 \\
(0.472)\end{array}$ & $\begin{array}{l}-0.408 \\
(0.446)\end{array}$ & $\begin{array}{l}-0.564 \\
(0.484)\end{array}$ & $\begin{array}{l}-0.440 \\
(0.458)\end{array}$ \\
\hline $\begin{array}{l}\text { Dummy variables for } \\
\text { family income deciles }\end{array}$ & No & No & No & Yes \\
\hline Number of obs. & 38,638 & 38,638 & 38,638 & 38,638 \\
\hline Pseudo-R ${ }^{2}$ & 10.72 & 10.77 & 10.71 & 10.80 \\
\hline
\end{tabular}

Source: Authors' calculations as described in the text. See also the notes for Table 2. We multiplied the estimated coefficients and standard errors for labor earnings by $10^{7}$; we multiplied those for labor earnings squared by $10^{12}$; and we multiplied those for labor earnings cubed by $10^{18}$. For dividend and interest income and for age squared, we multiplied the estimated coefficients and standard errors by $10^{6}$. Robust standard errors are in parentheses. The regressions are weighted by sample weights. 


\begin{tabular}{|c|c|c|c|c|c|}
\hline & $\begin{array}{c}\text { (1): } \\
\text { All } \\
\text { Households }\end{array}$ & $\begin{array}{c}(2): \\
\text { Age Only }\end{array}$ & $\begin{array}{c}\text { (3): } \\
\text { Education } \\
\text { Only }\end{array}$ & $\begin{array}{c}\text { (4): } \\
\text { Wage } \\
\text { Income } \\
\text { Quintile }\end{array}$ & $\begin{array}{c}\text { (5): Wage } \\
\text { Income } \\
\text { Quintile } \\
\text { within Age- } \\
\text { Education } \\
\text { Cell }\end{array}$ \\
\hline $\begin{array}{l}\text { Tax rate on } \\
\text { employment }\end{array}$ & $\begin{array}{c}-0.00161 \\
(0.000321)\end{array}$ & $\begin{array}{c}-0.00160 \\
(0.000324)\end{array}$ & $\begin{array}{c}-0.00161 \\
(0.000370)\end{array}$ & $\begin{array}{c}-0.00142 \\
(0.000337)\end{array}$ & $\begin{array}{c}-0.00101 \\
(0.000292)\end{array}$ \\
\hline $\begin{array}{l}\text { Upside tax rate } \\
\text { convexity }\end{array}$ & $\begin{array}{c}-0.00313 \\
(0.000730)\end{array}$ & $\begin{array}{c}-0.00289 \\
(0.000709)\end{array}$ & $\begin{array}{c}-0.00309 \\
(0.000741) \\
\end{array}$ & $\begin{array}{c}-0.00181 \\
(0.000666)\end{array}$ & $\begin{array}{c}-0.000192 \\
(0.000193)\end{array}$ \\
\hline $\begin{array}{l}\text { Number of } \\
\text { obs. }\end{array}$ & 38,638 & 38,638 & 38,638 & 38,638 & 38,638 \\
\hline Pseudo-R ${ }^{2}$ & 10.75 & 10.74 & 10.75 & 10.68 & 10.63 \\
\hline
\end{tabular}

Source: Authors' calculations as described in the text. See also the notes for Table 2. Robust standard errors are in parentheses. The regressions are weighted by sample weights. 


\begin{tabular}{|c|c|c|}
\hline & Marginal tax rate & Upside convexity \\
\hline \multicolumn{3}{|l|}{ Panel A: Income quintiles } \\
\hline Lowest quintile & $\begin{array}{c}-0.000333 \\
(0.000487)\end{array}$ & $\begin{array}{l}-0.00106 \\
(0.0115) \\
\end{array}$ \\
\hline $2^{\text {nd }}$ quintile & $\begin{array}{c}-0.00221 \\
(0.000695)\end{array}$ & $\begin{array}{l}-0.00167 \\
(0.0141)\end{array}$ \\
\hline $3^{\text {rd }}$ quintile & $\begin{array}{c}-0.000407 \\
(0.000626)\end{array}$ & $\begin{array}{l}-0.00219 \\
(0.00146)\end{array}$ \\
\hline $4^{\text {th }}$ quintile & $\begin{array}{c}-0.00295 \\
(0.000684)\end{array}$ & $\begin{array}{c}-0.00511 \\
(0.00149) \\
\end{array}$ \\
\hline Highest quintile & $\begin{array}{c}-0.00244 \\
(0.000556) \\
\end{array}$ & $\begin{array}{c}-0.00567 \\
(0.00178) \\
\end{array}$ \\
\hline \multicolumn{3}{|l|}{ Panel B: Educational attainment } \\
\hline Less than high school & $\begin{array}{c}-0.000913 \\
(0.000440) \\
\end{array}$ & $\begin{array}{c}-0.00220 \\
(0.00121) \\
\end{array}$ \\
\hline High school graduate & $\begin{array}{c}-0.00161 \\
(0.000414)\end{array}$ & $\begin{array}{l}-0.00279 \\
(0.00101)\end{array}$ \\
\hline Some college experience & $\begin{array}{c}-0.00157 \\
(0.000478)\end{array}$ & $\begin{array}{l}-0.00110 \\
(0.00134)\end{array}$ \\
\hline College graduate & $\begin{array}{c}-0.00227 \\
(0.000559)\end{array}$ & $\begin{array}{c}-0.00496 \\
(0.00167) \\
\end{array}$ \\
\hline Post-college experience & $\begin{array}{c}-0.00113 \\
(0.000852)\end{array}$ & $\begin{array}{l}-0.00605 \\
(0.00255)\end{array}$ \\
\hline \multicolumn{3}{|l|}{ Panel C: Age of head of household } \\
\hline Younger than 30 years old & $\begin{array}{c}-0.00183 \\
(0.000394) \\
\end{array}$ & $\begin{array}{c}-0.00205 \\
(0.000903) \\
\end{array}$ \\
\hline 30 years old $\leq$ age $<40$ years old & $\begin{array}{c}-0.00137 \\
(0.000406)\end{array}$ & $\begin{array}{c}-0.00434 \\
(0.00112) \\
\end{array}$ \\
\hline 40 years old $\leq$ age $<50$ years old & $\begin{array}{c}-0.00138 \\
(0.000521) \\
\end{array}$ & $\begin{array}{c}-0.00162 \\
(0.00165) \\
\end{array}$ \\
\hline 50 years old or older & $\begin{array}{c}-0.00147 \\
(0.000505)\end{array}$ & $\begin{array}{l}-0.00278 \\
(0.00207)\end{array}$ \\
\hline
\end{tabular}

Source: Authors' calculations, as described in the text. See also the notes for Table 2. Each panel reports estimates from a separate regression. The models also include the other covariates from the specifications in Table 2. The coefficients are marginal effects from probit estimated. Robust standard errors, clustered by household, are in parentheses. The regressions are weighted by sample weights. 
Table 6: Marginal Effects Estimated from Probits on All Job Changes and Job Search

\begin{tabular}{|c|c|c|c|c|}
\hline & \multicolumn{2}{|c|}{ All Job Changes } & \multicolumn{2}{|c|}{ Job Search } \\
\hline & $\begin{array}{c}\text { (1): All } \\
\text { Households }\end{array}$ & (2): Married Men & $\begin{array}{c}\text { (3): All } \\
\text { Households }\end{array}$ & (4): Married Men \\
\hline \begin{tabular}{|l|} 
Tax rate on \\
employment
\end{tabular} & $\begin{array}{l}-0.00267 \\
(0.000514)\end{array}$ & $\begin{array}{c}-0.00328 \\
(0.000674)\end{array}$ & $\begin{array}{c}0.000359 \\
(0.000267)\end{array}$ & $\begin{array}{c}0.00429 \\
(0.000337)\end{array}$ \\
\hline $\begin{array}{l}\text { Convexity in tax rate } \\
\text { (spread) }\end{array}$ & $\begin{array}{l}-0.00424 \\
(0.00109)\end{array}$ & $\begin{array}{l}-0.00488 \\
(0.00133)\end{array}$ & $\begin{array}{l}-0.000178 \\
(0.000526)\end{array}$ & $\begin{array}{l}-0.000133 \\
(0.000663)\end{array}$ \\
\hline Head's labor earnings & $\begin{array}{c}4.91 \\
(4.31)\end{array}$ & $\begin{array}{c}4.78 \\
(4.37)\end{array}$ & $\begin{array}{l}-8.70 \\
(2.64)\end{array}$ & $\begin{array}{l}-5.92 \\
(3.09)\end{array}$ \\
\hline $\begin{array}{l}\text { Head's labor earnings } \\
\text { squared }\end{array}$ & $\begin{array}{r}-0.823 \\
(1.01)\end{array}$ & $\begin{array}{l}-0.596 \\
(0.847)\end{array}$ & $\begin{array}{c}1.46 \\
(0.522)\end{array}$ & $\begin{array}{l}0.848 \\
(0.616)\end{array}$ \\
\hline $\begin{array}{l}\text { Spouse's labor } \\
\text { earnings }\end{array}$ & $\begin{array}{l}10.30 \\
(5.65)\end{array}$ & $\begin{array}{l}17.10 \\
(6.91)\end{array}$ & $\begin{array}{c}7.90 \\
(4.09)\end{array}$ & $\begin{array}{c}7.70 \\
(4.67)\end{array}$ \\
\hline \begin{tabular}{|l|} 
Spouse's labor \\
earnings squared
\end{tabular} & $\begin{array}{l}-7.35 \\
(9.84)\end{array}$ & $\begin{array}{l}-22.30 \\
(12.90)\end{array}$ & $\begin{array}{l}-28.10 \\
(12.70)\end{array}$ & $\begin{array}{l}-21.80 \\
(13.00)\end{array}$ \\
\hline $\begin{array}{l}\text { Dividend and interest } \\
\text { income }\end{array}$ & $\begin{array}{c}1.90 \\
(1.05)\end{array}$ & $\begin{array}{c}2.16 \\
(1.00)\end{array}$ & $\begin{array}{c}-0.122 \\
(0.581)\end{array}$ & $\begin{array}{l}-0.292 \\
(0.604)\end{array}$ \\
\hline $\begin{array}{l}\text { Other property } \\
\text { income }\end{array}$ & $\begin{array}{l}-0.761 \\
(0.672)\end{array}$ & $\begin{array}{l}-0.529 \\
(0.629)\end{array}$ & $\begin{array}{c}0.554 \\
(0.305)\end{array}$ & $\begin{array}{c}0.648 \\
(0.287)\end{array}$ \\
\hline Job tenure & $\begin{array}{c}-0.00590 \\
(0.000598)\end{array}$ & $\begin{array}{c}-0.00480 \\
(0.000603)\end{array}$ & $\begin{array}{c}-0.00179 \\
(0.000312)\end{array}$ & $\begin{array}{l}-0.00165 \\
(0.000331)\end{array}$ \\
\hline Union member & $\begin{array}{c}-0.0278 \\
(0.00093)\end{array}$ & $\begin{array}{c}-0.0201 \\
(0.00785)\end{array}$ & $\begin{array}{l}-0.00993 \\
(0.00354)\end{array}$ & $\begin{array}{l}-0.00919 \\
(0.00412)\end{array}$ \\
\hline Female head & $\begin{array}{l}-0.00463 \\
(0.01100)\end{array}$ & & $\begin{array}{c}0.00471 \\
(0.00527)\end{array}$ & \\
\hline Single $($ single $=1)$ & $\begin{array}{c}0.0220 \\
(0.00944)\end{array}$ & & $\begin{array}{c}0.00226 \\
(0.00461)\end{array}$ & \\
\hline Less than high school & $\begin{array}{c}0.0154 \\
(0.00940)\end{array}$ & $\begin{array}{c}0.0129 \\
(0.0104)\end{array}$ & $\begin{array}{c}0.00400 \\
(0.00483)\end{array}$ & $\begin{array}{c}0.00637 \\
(0.00598)\end{array}$ \\
\hline Some college & $\begin{array}{c}0.0281 \\
(0.00854)\end{array}$ & $\begin{array}{c}0.0289 \\
(0.00991)\end{array}$ & $\begin{array}{c}0.0207 \\
(0.00484)\end{array}$ & $\begin{array}{c}0.0216 \\
(0.00638)\end{array}$ \\
\hline College & $\begin{array}{c}0.0177 \\
(0.0119)\end{array}$ & $\begin{array}{c}0.0141 \\
(0.0132)\end{array}$ & $\begin{array}{c}0.0239 \\
(0.00669)\end{array}$ & $\begin{array}{c}0.0252 \\
(0.00862)\end{array}$ \\
\hline $\begin{array}{l}\text { Some post-college } \\
\text { education }\end{array}$ & $\begin{array}{c}0.0566 \\
(0.0178)\end{array}$ & $\begin{array}{c}0.0612 \\
(0.0207)\end{array}$ & $\begin{array}{c}0.0457 \\
(0.0126)\end{array}$ & $\begin{array}{c}0.0474 \\
(0.0164)\end{array}$ \\
\hline Number of obs. & 38,662 & 25,260 & 41,632 & 27,120 \\
\hline Pseudo-R ${ }^{2}$ & 9.57 & 8.33 & 15.12 & 13.62 \\
\hline
\end{tabular}

Source: Authors' calculations, as described in the text. Estimated models include census-region effects by year, number of children, age dummies for five-year age ranges for the head of household, dummy variables for wage-income quintile conditional on age-education cell, homeowners, minority status, marital transitions, and rural residents. Table 1 lists other sample restrictions. The estimated coefficients and standard errors for labor earnings are multiplied by $10^{7}$ and for labor earnings squared are multiplied by $10^{12}$. The estimated coefficients and standard errors for capital income and property income are multiplied by $10^{6}$. The marginal effects are evaluated at the mean values of the variables; for the dichotomous variables, marginal effects are for changes from zero to one. Robust standard errors, clustered by household, are in parentheses. The regressions are weighted by sample weights. 
Figure 1: Upside Tax Spread vs. Income

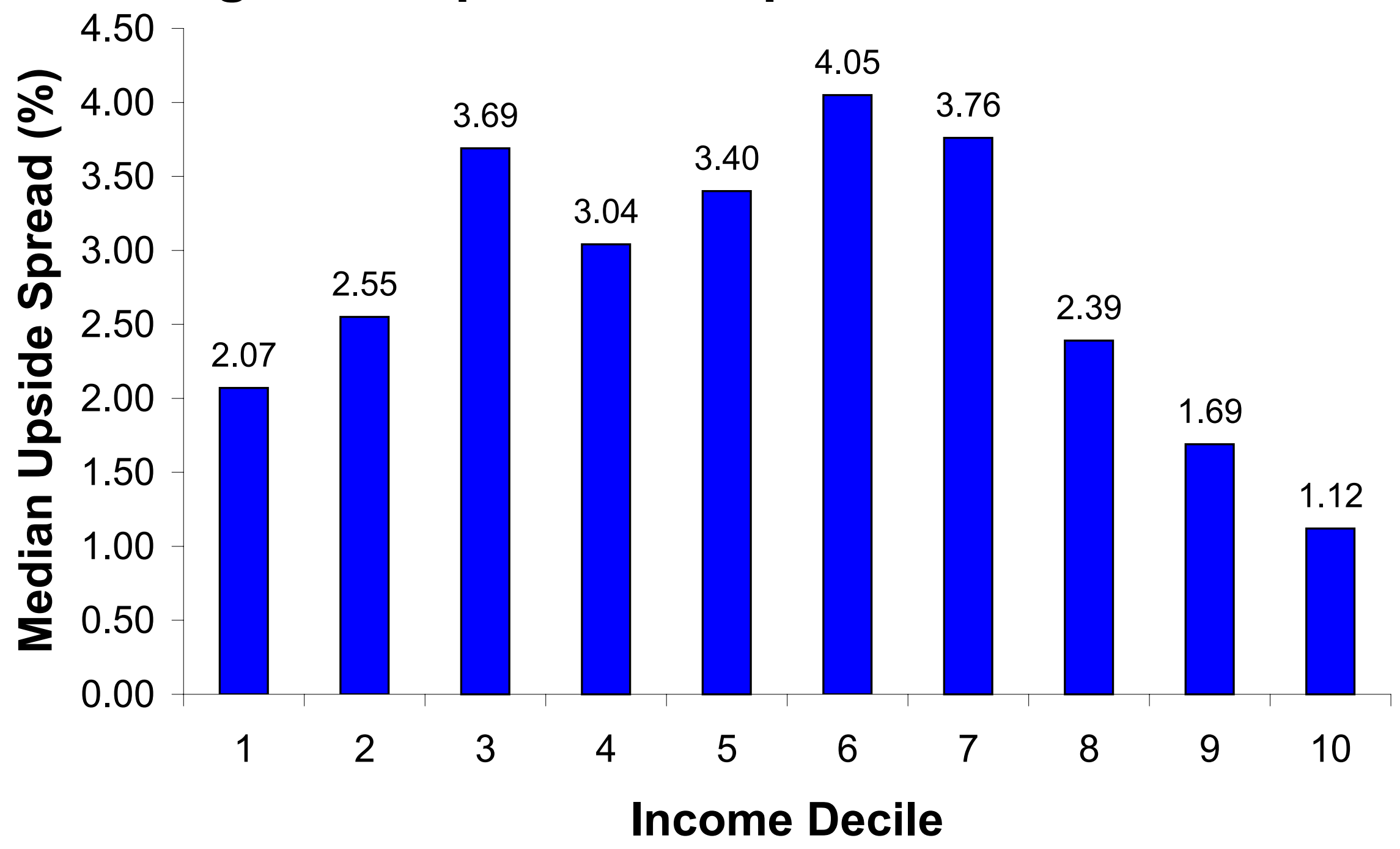

